\title{
RUBBLE-MOUND BREAKWATER WAVE-ATTENUATION AND STABILITY TESTS, OLCOTT HARBOR, NEW YORK
}

\section{Coastal Model Investigation}

\author{
by \\ Robert D. Carver \\ Coastal Engineering Research Center \\ DEPARTMENT OF THE ARMY \\ Waterways Experiment Station, Corps of Engineers \\ 3909 Halls Ferry Road, Vicksburg, Mississippi 39180-6199
}
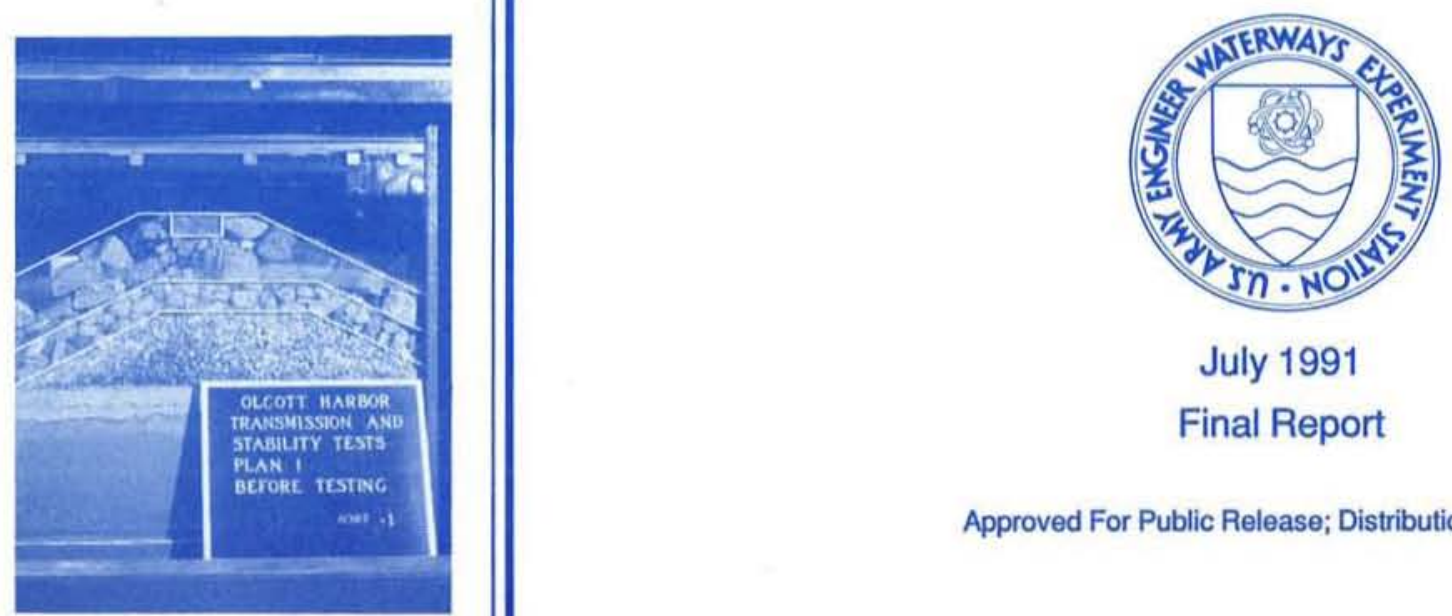

July 1991

Final Report

Approved For Public Release; Distribution Unlimited 
Destroy this report when no longer needed. Do not return it to the originator.

The findings in this report are not to be construed as an official

Department of the Army position unless so designated

by other authorized documents.

The contents of this report are not to be used for advertising, publication, or promotional purposes.

Citation of trade names does not constitute an

official endorsement or approval of the use of such commercial products. 
Public reporting burden for this collection of information is estimated to average 1 hour per response, including the time for reviewing instructions, searching existing data sources, gathering and maintaining the data needed, and completing and reviewing the collection of information. Send comments regarding this burden estimate or any other aspect of this collection of information, including suggestions for reducing this burden. to Washington Headquarters Services, Directorate for information Operations and Reports, 1215 Jefferson Davis Highway, Suite 1204, Arlington, VA 22202-4302, and to the Office of Management and Budget, Paperwork Reduction Project (0704-0 188), Washington, DC 20503.

1. AGENCY USE ONLY (Leave blank)

4. TITLE AND SUBTITLE

Rubble-Mound Breakwater Wave-Attenuation and Stability Tests, Olcott Harbor, New York; Coastal Model Investigation 6. AUTHOR(S)

Robert D. Carver

7. PERFORMING ORGANIZATION NAME(S) AND ADDRESS(ES)

USAE Waterways Experiment Station, Coastal Engineering Research Center, 3909 Halls Ferry Road, Vicksburg, MS 39180-6199

9. SPONSORING / MONITORING AGENCY NAME(S) AND ADDRESS(ES)

US Army Engineer District, Buffalo

Buffalo, NY 14207

\section{SUPPLEMENTARY NOTES}

Available from National Technical Information Service, 5285 Port Royal Road, Springfield, VA 22161.

12a. DISTRIBUTION / AVAILABILITY STATEMENT 12b. DISTRIBUTION CODE

Approved for public release; distribution unlimited

13. ABSTRACT (Maximum 200 words)

A 1:20-scale experimental model investigation was conducted to investigate the wave transmission response of a breakwater proposed for Olcott Harbor, New York. A check of the structure's stability showed the proposed section to be conservatively stable. Therefore, an alternate plan also was investigated in an attempt to reduce construction costs for the breakwater.

Based on model tests results, it was concluded that:

a. Both plans tested are stable designs for the maximum wave heights that can be expected to occur (6- to 10-sec waves at still-water levels of +4.3 and $+5.1 \mathrm{ft}$ low-water datum).

b. Maximum transmitted wave heights were 0.9 and $1.5 \mathrm{ft}$ for Plans 1 and $1 \mathrm{~A}$, respectively.

\begin{tabular}{|c|c|c|c|}
\hline $\begin{array}{l}\text { 14. SUBJECT TERMS } \\
\text { Armor stability }\end{array}$ & \multirow{2}{*}{\multicolumn{2}{|c|}{$\begin{array}{l}\text { Stone armor } \\
\text { Wave transmission }\end{array}$}} & \begin{tabular}{|l} 
15. NUMBER OF PAGES \\
28 \\
\end{tabular} \\
\hline $\begin{array}{l}\text { Breakwaters } \\
\text { Rubble mound }\end{array}$ & & & 16. PRICE CODE \\
\hline $\begin{array}{l}\text { 17. SECURIY CLASSIFICATION } \\
\text { OF REPORT }\end{array}$ & $\begin{array}{l}\text { 18. SECURITY CLASSIFICATION } \\
\text { OF THIS PAGE }\end{array}$ & $\begin{array}{l}\text { 19. SECURITY CLASSIFICATION } \\
\text { OF ABSTRACT }\end{array}$ & 20. LIMITATION OF ABSTRACT \\
\hline Unclassified & Unclassified & Unclassified & \\
\hline
\end{tabular}




\section{Contents}

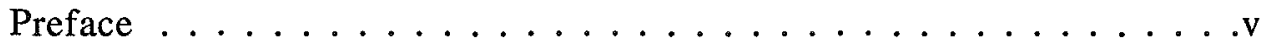

Conversion Factors, Non-SI to SI Units of Measurement . . . . . . . vii

1 -Introduction $\ldots \ldots \ldots \ldots \ldots \ldots \ldots \ldots \ldots \ldots \ldots \ldots \ldots \ldots \ldots$

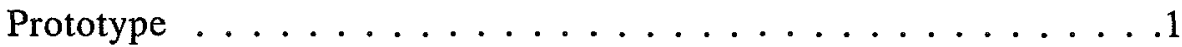

Purpose of Model Investigation $\ldots \ldots \ldots \ldots$

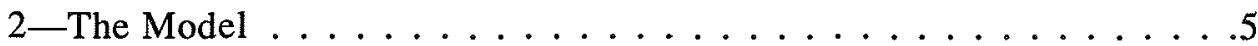

Model-Prototype Scale Relationships . . . . . . . . . . . . . 5

Test Equipment and Facilities . . . . . . . . . . . . . 6

3 -Tests and Results $\ldots \ldots \ldots \ldots$

Methods of Constructing Test Sections . . . . . . . . . . 9

Description of Plan $1 \ldots \ldots \ldots$

Selection of Test Conditions . . . . . . . . . . . 10

Test Results of Plan $1 \ldots \ldots \ldots$

Rationale and Description of Plan $1 \mathrm{~A} \ldots \ldots \ldots 11$

Test Results of Plan 1A . . . . . . . . . . . . . . 12

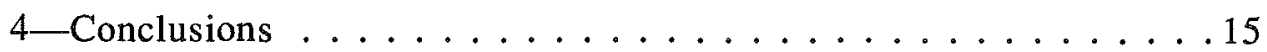

Tables 1-3

Photos 1-6

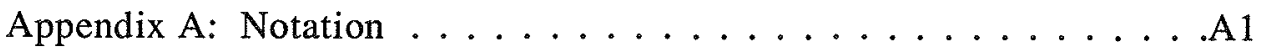




\section{Preface}

The model investigation described herein was requested by the US Army Engineer District, Buffalo (NCB), in a letter to the US Army Engineer Waterways Experiment Station (WES) dated 5 June 1990. Funding authorization was granted by NCB in Intra-Army Order No. NCB-IA-9027EJ, dated 5 June 1990.

The study was conducted by personnel of the Coastal Engineering Research Center (CERC), WES, under the general direction of Dr. James R. Houston, Chief, CERC, and Mr. Charles C. Calhoun, Jr., Assistant Chief, CERC. Direct guidance was provided by Messrs. C. E. Chatham, Chief, Wave Dynamics Division (WDD), and D. Donald Davidson, Chief, Wave Research Branch (WRB), WDD. Tests were conducted by Ms. Brenda J. Wright and Messrs. Willie G. Dubose and C. Ray Herrington, Engineering Technicians, under the direction of Mr. Robert D. Carver, Principal Investigator. This report was prepared by Mr. Carver.

COL Larry B. Fulton, EN, was the Commander and Director of WES during report publication. Dr. Robert W. Whalin was Technical Director. 


\section{Conversion Factors, Non-SI to SI Units of Measurement}

Non-SI units of measurement used in this report can be converted to SI units as follows:

\begin{tabular}{|l|l|l|}
\hline Multiply & By & To Obtain \\
\hline cubic feet & 0.02831685 & cubic metres \\
\hline degrees (angle) & 0.01745329 & radians \\
\hline feet & 0.3048 & metres \\
\hline pounds (mass) & 0.4535924 & kilograms \\
\hline pounds (mass) per cubic foot & 16.01846 & kilograms per cubic metre \\
\hline square feet & 0.09290304 & square metres \\
\hline tons (2,000 pounds, mass) & 907.1847 & kilograms \\
\hline
\end{tabular}




\section{Introduction}

\section{Prototype}

Olcott Harbor, New York, is situated at the mouth of Eighteen Mile Creek on the southern shore of Lake Ontario (Figures 1 and 2). Construction of an $850-\mathrm{ft}^{1}$-long east pier and an 873 -ft-long west pier was completed in 1918. The piers were originally of stone-filled timber crib construction with timber decks. In 1930, both piers were capped with stone and concrete. Repairs were made to the east pier in 1949 by driving rows of sheetpiling on each side of the pier, filling the voids with granular fill, and capping the structure with concrete. A similar repair procedure was performed on the west pier in 1963.

Presently, the entrance channel to the harbor area inside the mouth of the creek is safe only during calm weather. Proposed channel improvements will provide an urgently needed all weather entrance channel and additional berthing area for local craft. A feasibility study was prepared by the US Army Engineer District, Buffalo (NCB), and recommended construction of breakwater, jetty, and channel improvements.

Bottin and Acuff ${ }^{2}$ conducted a three-dimensional physical model study to develop the optimum plan for harbor improvements to meet small boat harbor wave height criteria. Improvements were designed to protect against waves entering through the new proposed harbor entrance and from waves overtopping the breakwater sections.

A table of factors for converting non-SI units of measurement to SI units is presented on page vii.

2 provements. Technical Report CERC-90-1. Vicksburg, MS: US Army Engineer Waterways Experiment Station. 
Chapter 1

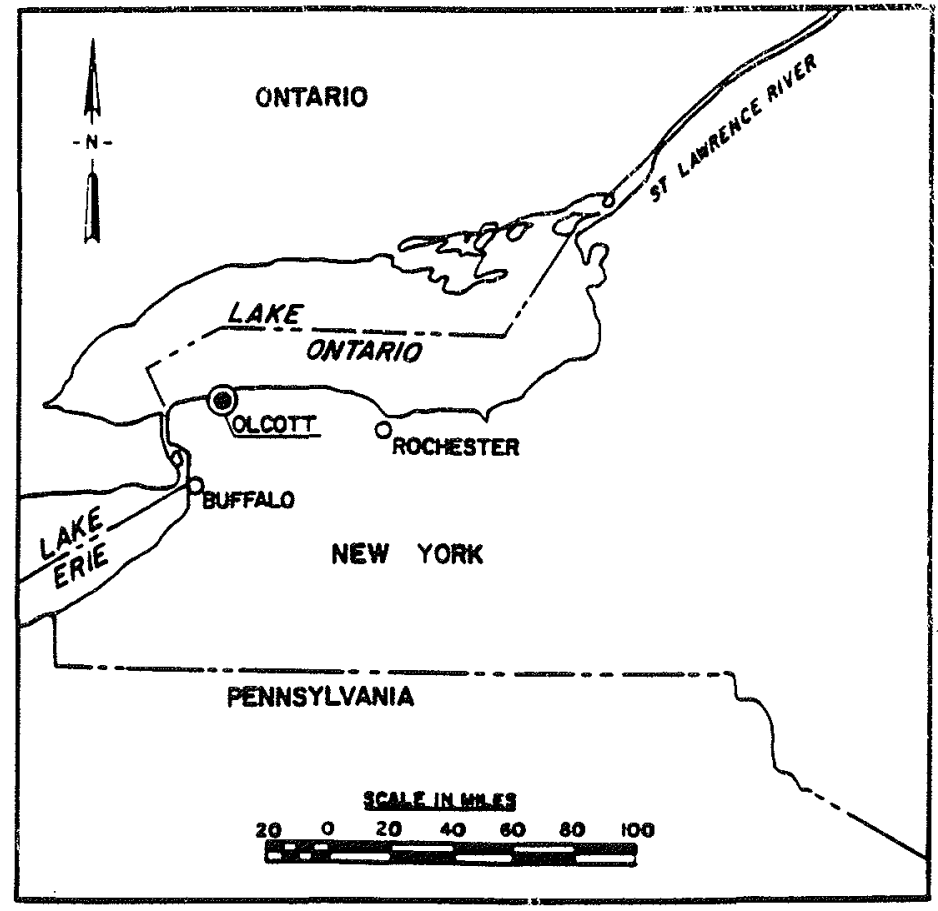

Figure 1. Project location

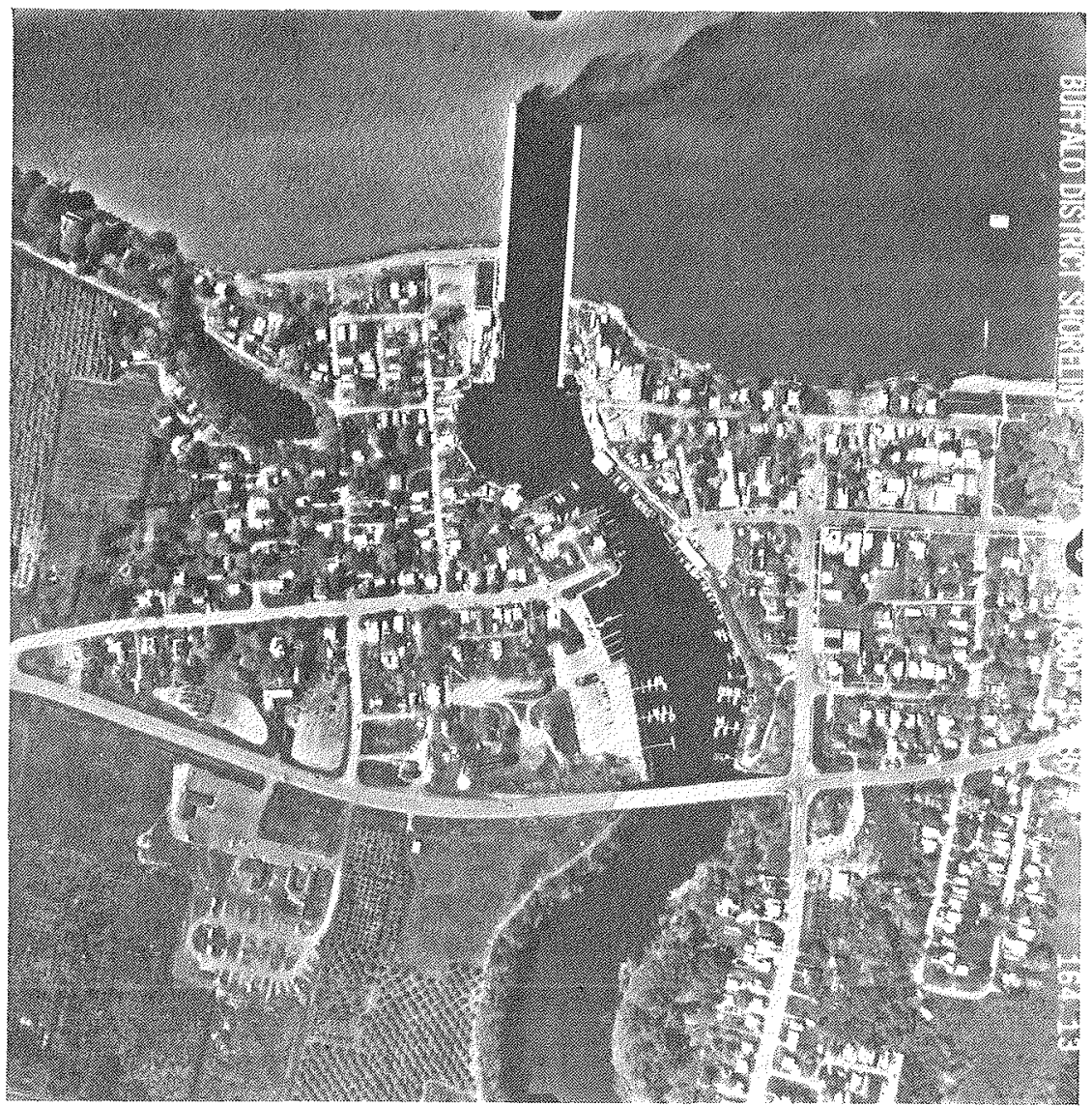

Figure 2. Aerial view of harbor 


\section{Purpose of Model Investigation}

The initial objective of this study was to investigate the wave transmission response of the proposed breakwater. A secondary benefit of tests conducted herein, a check of the structure's stability, showed the proposed section to be conservatively stable. Therefore, an alternate plan also was investigated in an attempt to reduce construction costs for the breakwater. 


\section{The Model}

\section{Model-Prototype Scale Relationships}

Tests were conducted at a geometrically undistorted scale of $1: 20$, model to prototype. Scale selection was based on the sizes of model armor available compared with the estimated size of prototype armor required for stability, elimination of wave transmission scale effects, preclusion of stability scale effects, ${ }^{1}$ and capabilities of the available wave tank. Based on Froude's model law ${ }^{2}$ and the linear scale of 1:20, the following model-prototype relations were derived. Dimensions are in terms of length $(\mathrm{L})^{3}$ and time (T).

\begin{tabular}{|l|l|l|}
\hline Characteristic & Dimension & $\begin{array}{l}\text { Model-Prototype } \\
\text { Scale Relation }\end{array}$ \\
\hline Length & $\mathrm{L}$ & $\mathrm{L}_{\mathrm{r}}=1: 20$ \\
\hline Area & $\mathrm{L}^{2}$ & $\mathrm{~A}_{\mathrm{r}}^{2}=\mathrm{L}_{\mathrm{r}}=1: 400$ \\
\hline Volume & $\mathrm{L}^{3}$ & $\mathrm{~V}_{\mathrm{r}}^{3}=\mathrm{L}_{\mathrm{r}}=1: 8000$ \\
\hline Time & $\mathrm{T}$ & $\mathrm{T}_{\mathrm{r}}^{1 / 2}=\mathrm{L}_{\mathrm{r}}=1: 4.47$ \\
\hline where $\quad \begin{array}{l}\mathrm{r}=\text { ratio of model quantities to prototype quantities } \\
\mathrm{A}=\text { area, } \mathrm{ft}^{2} \mathrm{ft}^{3} \\
\mathrm{~V}=\text { volume, }\end{array}$ \\
\hline
\end{tabular}

1

Hudson, R. Y. 1975 (Jun). Reliability of rubble-mound breakwater stability models. Miscellaneous Paper H-75-5. Vicksburg, MS: US Army Engineer Waterways Experiment Station.

2

Stevens, J. C. 1942. Hydraulic Models. Manuals of Engineering Practice No. 25.

New York: American Society of Civil Engineers.

3

For convenience, symbols and abbreviations are listed in the Notation (Appendix A). 
The specific weight of water used in model tests was assumed to be the same as the prototype and equal to $62.4 \mathrm{pcf}$. However, specific weights of model breakwater construction materials were not the same as their prototype counterparts. These variables were related using the following transference equation:

$$
\frac{\left(\mathrm{W}_{\mathrm{a}}\right)_{\mathrm{m}}}{\left(\mathrm{W}_{\mathrm{a}}\right)_{\mathrm{p}}}=\frac{\left(\gamma_{\mathrm{a}}\right)_{\mathrm{m}}}{\left(\gamma_{\mathrm{a}}\right)_{\mathrm{p}}}\left(\frac{\mathrm{L}_{\mathrm{m}}}{\mathrm{L}_{\mathrm{p}}}\right)^{3}\left[\frac{\left(\mathrm{S}_{\mathrm{a}}\right)_{\mathrm{p}}-1}{\left(\mathrm{~S}_{\mathrm{a}}\right)_{\mathrm{m}}-1}\right]^{3}
$$

where

$$
\begin{aligned}
& \mathrm{W}_{\mathrm{a}}=\text { weight of individual armor unit, } \mathrm{lb} \\
& \mathrm{a}=\text { armor stone } \\
& \mathrm{m}=\text { model quantities } \\
& \mathrm{p}=\text { prototype quantities } \\
& \gamma_{\mathrm{a}}=\text { specific weight of armor unit, pcf } \\
& \mathrm{S}_{\mathrm{a}}=\text { specific weight of individual armor unit relative to water } \\
& \quad \text { in which breakwater is constructed }
\end{aligned}
$$

\section{Test Equipment and Facilities}

All tests were conducted in a concrete wave flume $3 \mathrm{ft}$ wide and $150 \mathrm{ft}$ long (Figure 3). A 1V-on-100H slope, representative of the existing prototype lake bottom, was molded lakeward of the test section. Irregular waves were generated by a hydraulically actuated piston-type wave machine. The test section was installed approximately $84.3 \mathrm{ft}$ from the wave board.

Wave data were collected on electrical capacitance wave gages. Wave signal generation and data acquisition were controlled using a DEC MicroVax I computer. Wave data analyses were accomplished using a DEC VAX 3600. 


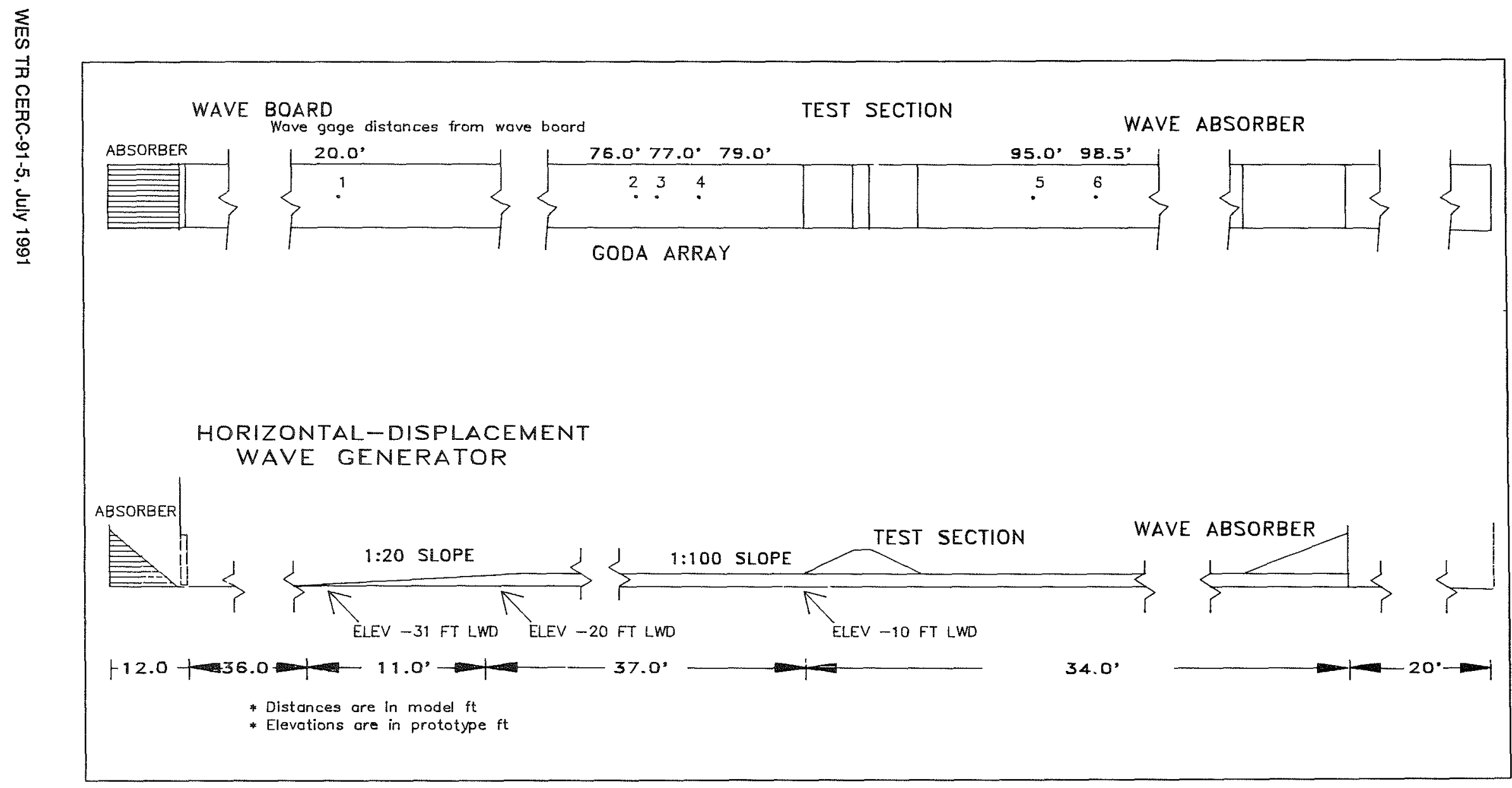

Figure 3. Wave flume cross section 


\section{Tests and Results}

\section{Method of Constructing Test Sections}

All experimental breakwater sections were constructed to reproduce as closely as possible results of the usual methods of constructing full-scale breakwaters. The core material was dampened as it was dumped by bucket or shovel into the flume and was compacted with hand trowels to simulate natural consolidation resulting from wave action during construction of the prototype structure. Once the core material was in place, it was sprayed with a low-velocity water hose to ensure adequate compaction of the material. The underlayer stone then was added by shovel and smoothed to grade by hand or with trowels. Armor units used in the cover layers were placed in a random manner corresponding to work performed by a general coastal contractor; i.e., they were individually placed but were laid down without special orientation or fitting. After each test, the armor units were removed from the breakwater, all of the underlayer stones were replaced to the grade of the original test section, and the armor was replaced.

\section{Description of Plan 1}

Plan 1 (Figure 4 and Photos 1 and 2) was constructed to a crown elevation of $+14 \mathrm{ft}$ low-water datum (lwd) and used armor slopes of $1 \mathrm{~V}$ on $2 \mathrm{H}$ both lakeside and harbor side. A crown width of $16.2 \mathrm{ft}$, equivalent to two armor-stone diameters plus a 7-ft-wide walkway, was used. The lakeside slope was armored with two layers of 4- to 11-ton stone, whereas the harbor-side slope used only one layer of 4- to 11-ton stone. In an effort to preclude toe slippage, the first row of armor stone at the toe of each slope used the largest size stone that was available in the specified armor stone range. 


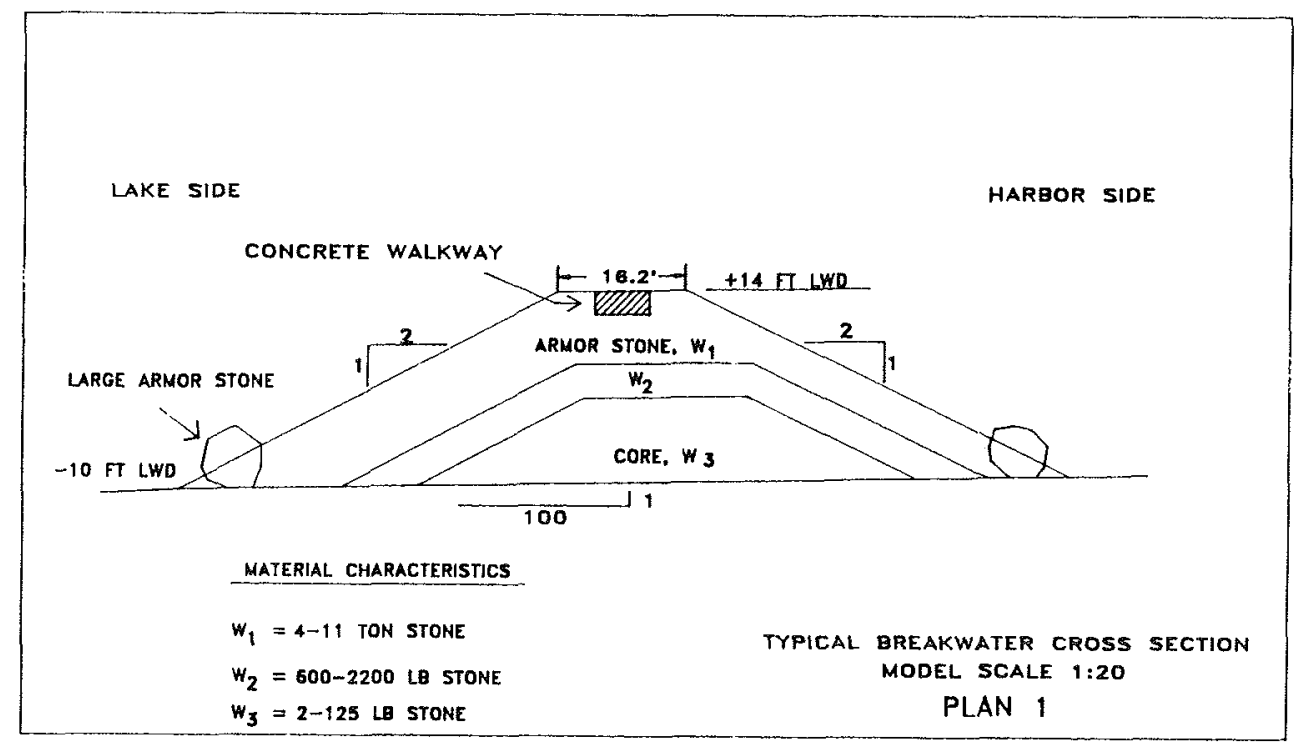

Figure 4. Cross section of Plan 1

\section{Selection of Test Conditions}

Based on siting of the breakwater in shallow water, tests were conducted with a Texel, Marsen, Arsloe (TMA) spectrum using peak wave periods $\left(\mathrm{T}_{\mathrm{p}}\right)$ of $6,7,8,9$, and $10 \mathrm{sec}$. The wave basin was calibrated for wave heights ( $\mathrm{H}_{\text {mo }}$ values) of 3 to $12 \mathrm{ft}$ measured in front of the wave generator and in front of the structure. Transmitted wave heights were measured 100 and $150 \mathrm{ft}$ shoreward of the breakwater. Goda and Suzuki's ${ }^{1}$ method was used to resolve the incident and reflected spectra.

\section{Test Results of Plan 1}

Wave-attenuation test results are presented in Tables 1 and 2. Transmission coefficients $\left(\mathrm{H}_{\mathrm{t}} / \mathrm{H}_{\mathrm{i}}\right)$ are based on incident wave heights measured at the wave generator because these wave heights relate to the percent time of occurrence wave tables used in the harbor model. ${ }^{2}$ In general, the data show that (a) there is little difference between transmitted wave heights measured at 100 to $150 \mathrm{ft}$ shoreward of the structure and (b) if

Goda, Y., and Suzuki, Y. 1976. Estimation of incident and reflected waves in random wave experiments. In Proceedings, 15 th international conference on coastal engineering. Honolulu, Hawaii.

2

Bottin and Acuff, op. cit. 
the incident wave height is held constant and the wave period is increased, transmitted wave heights increase. Maximum transmitted wave heights of $0.9 \mathrm{ft}$ were observed at the $9-$ and 10 -sec wave periods.

Observations of incident wave forms, made during the wave attenuation tests, showed that the most severe wave conditions which experimentally could be made to attack the section for the selected conditions occurred at the 10 -sec peak period with maximum wave height of about $11 \mathrm{ft}$. Therefore, it was decided the stability response of the proposed section could be adequately evaluated by subjecting the structure to the following storm-surge hydrograph:

\begin{tabular}{|l|l|l|l|l|}
\hline Step & $\begin{array}{l}\text { Swl } \\
\text { ft, Iwd }\end{array}$ & $\begin{array}{l}\text { Wave Period } \\
T_{p}, \text { sec }\end{array}$ & $\begin{array}{l}\text { Wave Height } \\
\mathbf{H}_{\text {mo }}, \mathrm{ft}\end{array}$ & $\begin{array}{l}\text { Prototype } \\
\text { Duration, } \mathrm{hr}\end{array}$ \\
\hline 1 & +4.3 & 10 & 11.1 & 4 \\
\hline 2 & +5.1 & 10 & 11.2 & 4 \\
\hline 3 & +4.3 & 10 & 11.1 & 4 \\
\hline \hline Note: Swl = still-water level.
\end{tabular}

As evidenced in Photos 3 and 4, Plan 1 exhibited an excellent stability response. Minor rocking of a few armor stones was observed; however, none were displaced.

\section{Rationale and Description of Plan 1A}

Based on the excellent stability response of Plan 1, it was decided to investigate alternative schemes that might reduce the structure's cost without significantly affecting its functional performance. Some of the factors that govern material volumes and costs are elevation and width of the crown, type and weight of armor, and slope on which the armor is placed. Based on discussions between NCB and US Army Engineer Waterways Experiment Station, it was decided that, in this particular study, the greatest cost savings with the least probable impact on functionality could probably be achieved by lowering the crown elevation.

Plan 1A was the same as Plan 1 except a toe elevation of $-11.5 \mathrm{ft}$ lwd and crown elevation of $+12.5 \mathrm{ft}$ lwd were used. This simulation was achieved by simply increasing the water depth $1.5 \mathrm{ft}$ and assuming the new depth also represented an swl of $+5.1 \mathrm{ft}$ lwd. This approach reduced the freeboard by $1.5 \mathrm{ft}$ and effectively achieved the same results (relative to transmission) as would have been achieved by lowering the model structure $1.5 \mathrm{ft}$. 


\section{Test Results of Plan 1A}

Wave attenuation test results are presented in Table 3 . These data show the same general trends as those observed with Plan 1. As would be expected with the reduced crown elevation, Plan 1A showed increased wave transmission. A maximum transmitted wave of $1.5 \mathrm{ft}$ was observed for the $10-\mathrm{sec}$ wave period. Figure 5 shows average wave transmission coefficient for the 150-ft spacing versus peak wave period for Plans 1 and $1 \mathrm{~A}$.

Plan 1A was stable. Minor rocking of a few armor units was observed; however, none were displaced, and the integrity of the section was not jeopardized. Photos 5 and 6 show the structure at the conclusion of testing.

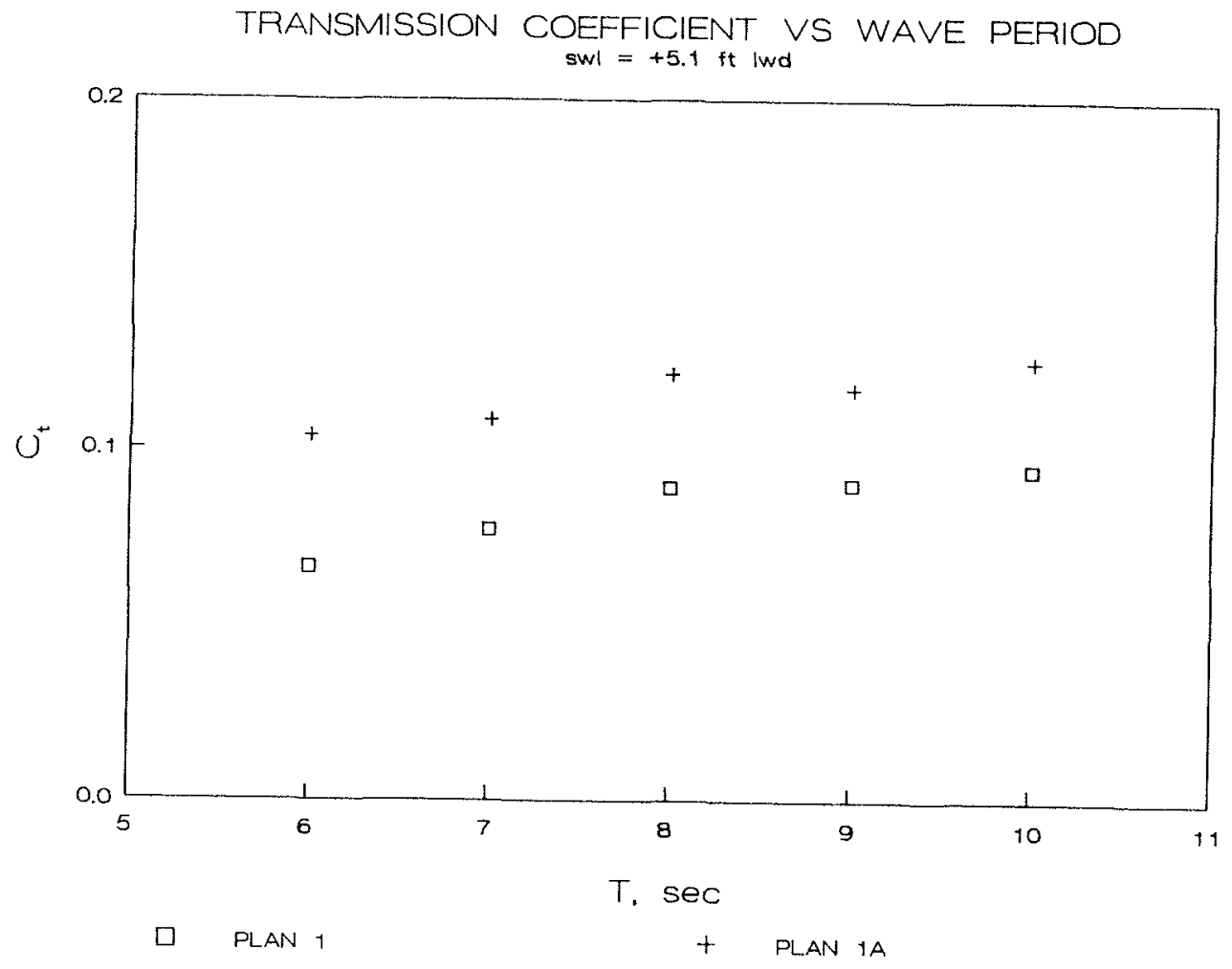

Figure 5. Coefficient of transmission $\left(C_{t}\right)$ versus wave period $\left(T_{p}\right)$ 


\section{Conclusions}

Based on assumptions, tests, and results reported herein, it is concluded that:

a. Plans 1 and $1 \mathrm{~A}$ are stable designs for the maximum wave heights that can be expected to occur (6- to $10-\mathrm{sec}$ waves at swl's of +4.3 and $+5.1 \mathrm{ft}$ lwd.)

b. Maximum transmitted wave heights were 0.9 and $1.5 \mathrm{ft}$ for Plans 1 and $1 \mathrm{~A}$, respectively. 


\begin{tabular}{|c|c|c|c|c|c|c|}
\hline \multicolumn{7}{|c|}{$\begin{array}{l}\text { Table } 1 \\
\text { Incident and Transmitted Wave Heights: Plan 1, swl }=+4.3 \mathrm{ft} \text { Iwd }\end{array}$} \\
\hline $\begin{array}{l}\text { Wave } \\
\text { Period } \\
\text { sec }\end{array}$ & $\begin{array}{l}\text { Incident } \\
\text { Wave Height } \\
\mathrm{ft}^{1}\end{array}$ & $\begin{array}{l}\text { Incident } \\
\text { Wave Height } \\
\mathrm{ft}^{2}\end{array}$ & $\begin{array}{l}\text { Transmitted } \\
\text { Wave Height, } \mathrm{ft} \\
100 \mathrm{ft} \text { shoreward }\end{array}$ & $\mathrm{C}^{3}$ & $\begin{array}{l}\text { Transmitted } \\
\text { Wave Height, } \mathrm{ft} \\
150 \mathrm{ft} \text { shoreward }\end{array}$ & $c_{t}{ }^{3}$ \\
\hline 6.0 & 2.7 & 3.1 & 0.2 & 0.06 & 0.2 & 0.06 \\
\hline 6.0 & 4.1 & 4.6 & 0.3 & 0.07 & 0.3 & 0.07 \\
\hline 6.0 & 5.2 & 6.1 & 0.4 & 0.07 & 0.4 & 0.07 \\
\hline \multirow[t]{2}{*}{6.0} & 6.2 & 7.4 & 0.4 & 0.05 & 0.4 & 0.05 \\
\hline & & & \multicolumn{2}{|r|}{$\overline{\mathrm{C}}_{t}^{4}=0.06$} & \multicolumn{2}{|r|}{$\bar{C}_{1}=0.06$} \\
\hline 7.0 & 3.5 & 3.9 & 0.3 & 0.08 & 0.3 & 0.08 \\
\hline 7.0 & 2.5 & 5.8 & 0.4 & 0.07 & 0.4 & 0.07 \\
\hline 7.0 & 6.6 & 7.6 & 0.5 & 0.07 & 0.5 & 0.07 \\
\hline \multirow[t]{2}{*}{7.0} & 7.3 & 9.1 & 0.6 & 0.07 & 0.5 & 0.05 \\
\hline & & & \multicolumn{2}{|r|}{$\bar{C}_{t}=0.07$} & \multicolumn{2}{|r|}{$\bar{C}_{t}=0.07$} \\
\hline 8.0 & 3.6 & 3.9 & 0.4 & 0.10 & 0.4 & 0.10 \\
\hline 8.0 & 5.4 & 5.9 & 0.5 & 0.08 & 0.5 & 0.08 \\
\hline 8.0 & 6.8 & 7.7 & 0.5 & 0.06 & 0.6 & 0.08 \\
\hline \multirow[t]{2}{*}{8.0} & 7.8 & 9.4 & 0.6 & 0.06 & 0.7 & 0.07 \\
\hline & & & \multicolumn{2}{|r|}{$\bar{C}_{t}=0.08$} & \multicolumn{2}{|r|}{$\bar{C}_{t}=0.08$} \\
\hline 9.0 & 4.4 & 4.8 & 0.4 & 0.08 & 0.5 & 0.10 \\
\hline 9.0 & 6.5 & 7.1 & 0.6 & 0.08 & 0.6 & 0.08 \\
\hline 9.0 & 7.7 & 9.1 & 0.7 & 0.08 & 0.7 & 0.08 \\
\hline \multirow[t]{2}{*}{9.0} & 8.3 & 11.0 & 0.7 & 0.06 & 0.7 & 0.06 \\
\hline & & & \multicolumn{2}{|r|}{$\bar{C}_{t}=0.08$} & \multicolumn{2}{|r|}{$\bar{C}_{t}=0.08$} \\
\hline 10.0 & 4.5 & 4.6 & 0.5 & 0.11 & 0.5 & 0.11 \\
\hline 10.0 & 6.5 & 7.0 & 0.6 & 0.09 & 0.6 & 0.09 \\
\hline 10.0 & 7.9 & 9.4 & 0.7 & 0.07 & 0.7 & 0.07 \\
\hline \multirow[t]{2}{*}{10.0} & 8.3 & 11.1 & 0.8 & 0.07 & 0.8 & 0.07 \\
\hline & & & \multicolumn{2}{|r|}{$\bar{C}_{t}=0.09$} & \multicolumn{2}{|r|}{$\bar{C}_{t}=0.09$} \\
\hline $\begin{array}{l}{ }^{1} \text { Measur } \\
{ }^{2} \text { Measur } \\
{ }^{3} \text { Transm } \\
{ }^{4} \bar{C}_{t}=a v\end{array}$ & $\begin{array}{l}\text { at Goda arra } \\
\text { t wave gene } \\
\text { on coefficien } \\
\Theta C_{t} \text {. }\end{array}$ & $\begin{array}{l}\text { in front of struc } \\
\text { ator. }\end{array}$ &.. & asured at $t$ & wave generator. & \\
\hline
\end{tabular}


Table 2

Incident and Transmitted Wave Heights: Plan 1, swl $=+5.1 \mathrm{ft} \mathrm{lwd}$

\begin{tabular}{|c|c|c|c|c|c|c|}
\hline $\begin{array}{l}\text { Wave } \\
\text { Period } \\
\text { sec }\end{array}$ & $\begin{array}{l}\text { Incident } \\
\text { Wave Height } \\
\mathrm{ft}^{1}\end{array}$ & $\begin{array}{l}\text { Incident } \\
\text { Wave Height } \\
\mathrm{ft}^{2}\end{array}$ & $\begin{array}{l}\text { Transmitted } \\
\text { Wave Height, ft } \\
100 \mathrm{ft} \text { shoreward }\end{array}$ & $\mathrm{c}_{t}{ }^{3}$ & $\begin{array}{l}\text { Transmitted } \\
\text { Wave Height, ft } \\
150 \mathrm{ft} \text { shoreward }\end{array}$ & $c_{t}{ }^{3}$ \\
\hline 6.0 & 2.8 & 3.1 & 0.2 & 0.06 & 0.2 & 0.06 \\
\hline 6.0 & 4.1 & 4.6 & 0.3 & 0.07 & 0.3 & 0.07 \\
\hline 6.0 & 5.3 & 6.0 & 0.4 & 0.07 & 0.4 & 0.07 \\
\hline \multirow[t]{2}{*}{6.0} & 6.3 & 7.3 & 0.5 & 0.07 & 0.5 & 0.07 \\
\hline & & & \multicolumn{2}{|r|}{$\bar{C}_{t}^{4}=0.07$} & \multicolumn{2}{|r|}{$\bar{C}_{t}=0.07$} \\
\hline 7.0 & 3.6 & 3.9 & 0.3 & 0.08 & 0.3 & 0.08 \\
\hline 7.0 & 5.4 & 5.8 & 0.5 & 0.09 & 0.5 & 0.09 \\
\hline 7.0 & 6.8 & 7.6 & 0.6 & 0.08 & 0.6 & 0.08 \\
\hline \multirow[t]{2}{*}{7.0} & 7.8 & 9.1 & 0.6 & 0.07 & 0.6 & 0.07 \\
\hline & & & \multicolumn{2}{|r|}{$\bar{C}_{t}=0.08$} & \multicolumn{2}{|r|}{$\bar{C}_{t}=0.08$} \\
\hline 8.0 & 3.6 & 3.8 & 0.4 & 0.11 & 0.4 & 0.11 \\
\hline 8.0 & 5.6 & 5.8 & 0.5 & 0.09 & 0.5 & 0.09 \\
\hline 8.0 & 7.0 & 7.8 & 0.7 & 0.09 & 0.7 & 0.09 \\
\hline \multirow[t]{2}{*}{8.0} & 7.9 & 9.3 & 0.8 & 0.09 & 0.7 & 0.08 \\
\hline & & & \multicolumn{2}{|r|}{$\bar{C}_{t}=0.09$} & \multicolumn{2}{|r|}{$\bar{C}_{\mathrm{t}}=0.09$} \\
\hline 9.0 & 4.5 & 4.7 & 0.5 & 0.11 & 0.5 & 0.11 \\
\hline 9.0 & 6.6 & 7.1 & 0.7 & 0.10 & 0.6 & 0.08 \\
\hline 9.0 & 8.0 & 9.1 & 0.8 & 0.09 & 0.8 & 0.09 \\
\hline \multirow[t]{2}{*}{9.0} & 8.7 & 11.0 & 0.9 & 0.08 & 0.9 & 0.08 \\
\hline & & & \multicolumn{2}{|r|}{$\overline{\mathrm{C}}_{\mathrm{t}}=0.09$} & \multicolumn{2}{|r|}{$\bar{C}_{\mathrm{t}}=0.09$} \\
\hline 10.0 & 4.7 & 4.8 & 0.6 & 0.13 & 0.5 & 0.10 \\
\hline 10.0 & 6.8 & 7.1 & 0.7 & 0.10 & .0 .7 & 0.10 \\
\hline 10.0 & 8.2 & 9.5 & 0.9 & 0.09 & 0.9 & 0.09 \\
\hline \multirow[t]{2}{*}{10.0} & 8.6 & 11.2 & 0.9 & 0.08 & 0.9 & 0.08 \\
\hline & & & \multicolumn{2}{|r|}{$\bar{C}_{t}=0.10$} & \multicolumn{2}{|r|}{$\bar{C}_{t}=0.09$} \\
\hline \multicolumn{7}{|c|}{$\begin{array}{l}{ }^{1} \text { Measured at Goda array in front of structure. } \\
{ }^{2} \text { Measured at wave generator. } \\
{ }^{3} \text { Transmission coefficient }\left(H_{t} / H_{i}\right) \text { based on incident wave heights measured at the wave generator. } \\
{ }^{4} \bar{C}_{t}=\text { average } C_{t} \text {. }\end{array}$} \\
\hline
\end{tabular}




\begin{tabular}{|c|c|c|c|c|c|c|}
\hline \multicolumn{7}{|c|}{$\begin{array}{l}\text { Table } 3 \\
\text { Incident and Transmitted Wave Heights: Plan } 1 A_{3} s w I=45.1 \text { ft Iwd }\end{array}$} \\
\hline $\begin{array}{l}\text { Wave } \\
\text { Period } \\
\text { sec }\end{array}$ & $\begin{array}{l}\text { Incident } \\
\text { Wave Height } \\
\mathrm{ft}^{1}\end{array}$ & $\begin{array}{l}\text { Incident } \\
\text { Wave Helght } \\
n^{2}\end{array}$ & $\begin{array}{l}\text { Transmitted } \\
\text { Wave Helght, it } \\
\text { 100 ft shoreward }\end{array}$ & $c_{1}^{3}$ & $\begin{array}{l}\text { Transmitted } \\
\text { Wave Helght, ft } \\
150 \mathrm{ft} \text { shoreward }\end{array}$ & $c_{t}^{3}$ \\
\hline 6.0 & 2.8 & 3.3 & 0.4 & 0.12 & 0.4 & 0.12 \\
\hline 6.0 & 4.2 & 4.8 & 0.5 & 0.10 & 0.5 & 0.10 \\
\hline 6.0 & 5.5 & 6.2 & 0.6 & 0.10 & 0.6 & 0.10 \\
\hline \multirow[t]{2}{*}{6.0} & 6.6 & 7.5 & 0.7 & 0.09 & 0.7 & 0.09 \\
\hline & & & \multicolumn{2}{|r|}{$\bar{C}_{t}^{4}=0.10$} & \multicolumn{2}{|r|}{$\overline{\mathrm{C}}_{\mathrm{t}}=0.10$} \\
\hline 7.0 & 3.6 & 4.3 & 0.6 & 0.14 & 0.6 & 0.14 \\
\hline 7.0 & 5.3 & 6.4 & 0.8 & 0.13 & 0.7 & 0.11 \\
\hline 7.0 & 6.7 & 8.4 & 0.9 & 0.11 & 0.8 & 0.10 \\
\hline \multirow[t]{2}{*}{7.0} & 7.7 & 10.0 & 1.0 & 0.10 & 0.9 & 0.09 \\
\hline & & & \multicolumn{2}{|r|}{$\bar{C}_{t}=0.12$} & \multicolumn{2}{|r|}{$\bar{C}_{t}=0.11$} \\
\hline 8.0 & 3.8 & 4.1 & 0.6 & 0.15 & 0.6 & 0.15 \\
\hline 8.0 & 5.7 & 6.2 & 0.8 & 0.13 & 0.8 & 0.13 \\
\hline 8.0 & 7.3 & 8.1 & 0.9 & 0.11 & 0.9 & 0.11 \\
\hline \multirow[t]{2}{*}{8.0} & 8.3 & 10.0 & 1.1 & 0.11 & 1.0 & 0.10 \\
\hline & & & \multicolumn{2}{|r|}{$\bar{C}_{t}=0.12$} & \multicolumn{2}{|r|}{$\overline{\mathrm{C}}_{\mathrm{t}}=0.12$} \\
\hline 9.0 & 4.4 & 5.1 & 0.8 & 0.16 & 0.7 & 0.14 \\
\hline 9.0 & 6.5 & 7.5 & 1.0 & 0.13 & 0.9 & 0.12 \\
\hline 9.0 & 8.0 & 9.8 & 1.2 & 0.12 & 1.1 & 0.11 \\
\hline \multirow[t]{2}{*}{9.0} & 8.9 & 12.0 & 1.3 & 0.11 & 1.2 & 0.10 \\
\hline & & & \multicolumn{2}{|r|}{$\overline{\mathrm{C}}_{\mathrm{t}}=0.13$} & \multicolumn{2}{|r|}{$\bar{C}_{t}=0.12$} \\
\hline 10.0 & 4.6 & 5.2 & 0.8 & 0.15 & 0.7 & 0.13 \\
\hline 10.0 & 6.7 & 7.9 & 1.1 & 0.14 & 1.0 & 0.13 \\
\hline 10.0 & 8.2 & 10.3 & 1.3 & 0.13 & 1.3 & 0.13 \\
\hline \multirow[t]{2}{*}{10.0} & 9.1 & 12.3 & 1.5 & 0.12 & 1.4 & 0.11 \\
\hline & & & \multicolumn{2}{|r|}{$\bar{c}_{\mathrm{t}}=0.14$} & \multicolumn{2}{|r|}{$\bar{c}_{t}=0.13$} \\
\hline $\begin{array}{l}{ }^{1} \text { Measu } \\
{ }^{2} \text { Measu } \\
{ }^{3} \text { Transm } \\
{ }^{4} \overline{\mathrm{C}}_{\mathrm{t}}=\mathrm{av}\end{array}$ & $\begin{array}{l}\text { al Goda arra } \\
\text { at wave gene } \\
\text { on coefficien } \\
C_{t} \text {. }\end{array}$ & $\begin{array}{l}\text { in front of stry } \\
\text { ator. }\end{array}$ & 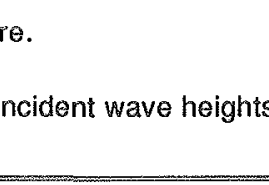 & asured at 1 & e wave generator. & \\
\hline
\end{tabular}



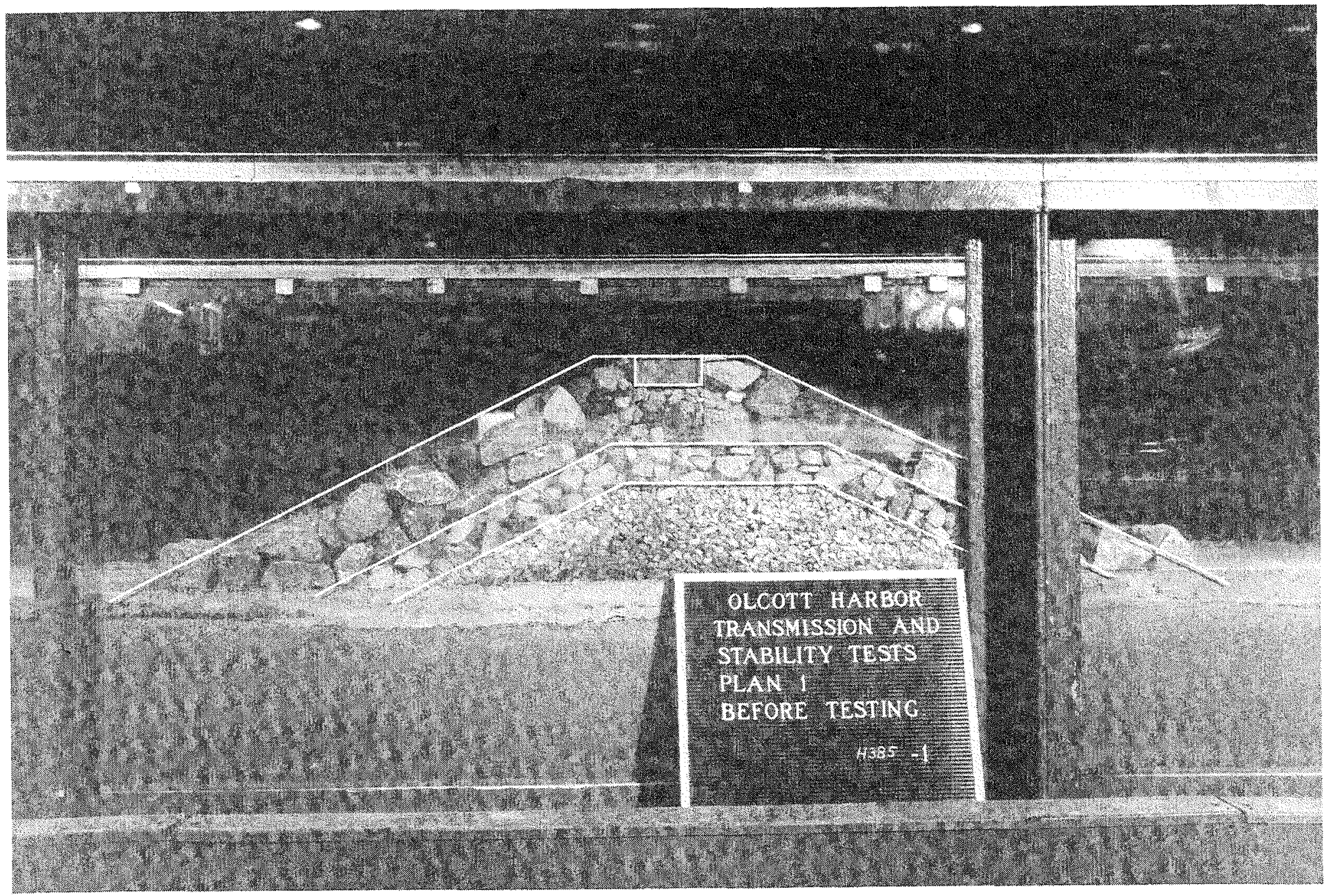

Photo 1. Side view of Plan 1 before wave attack 


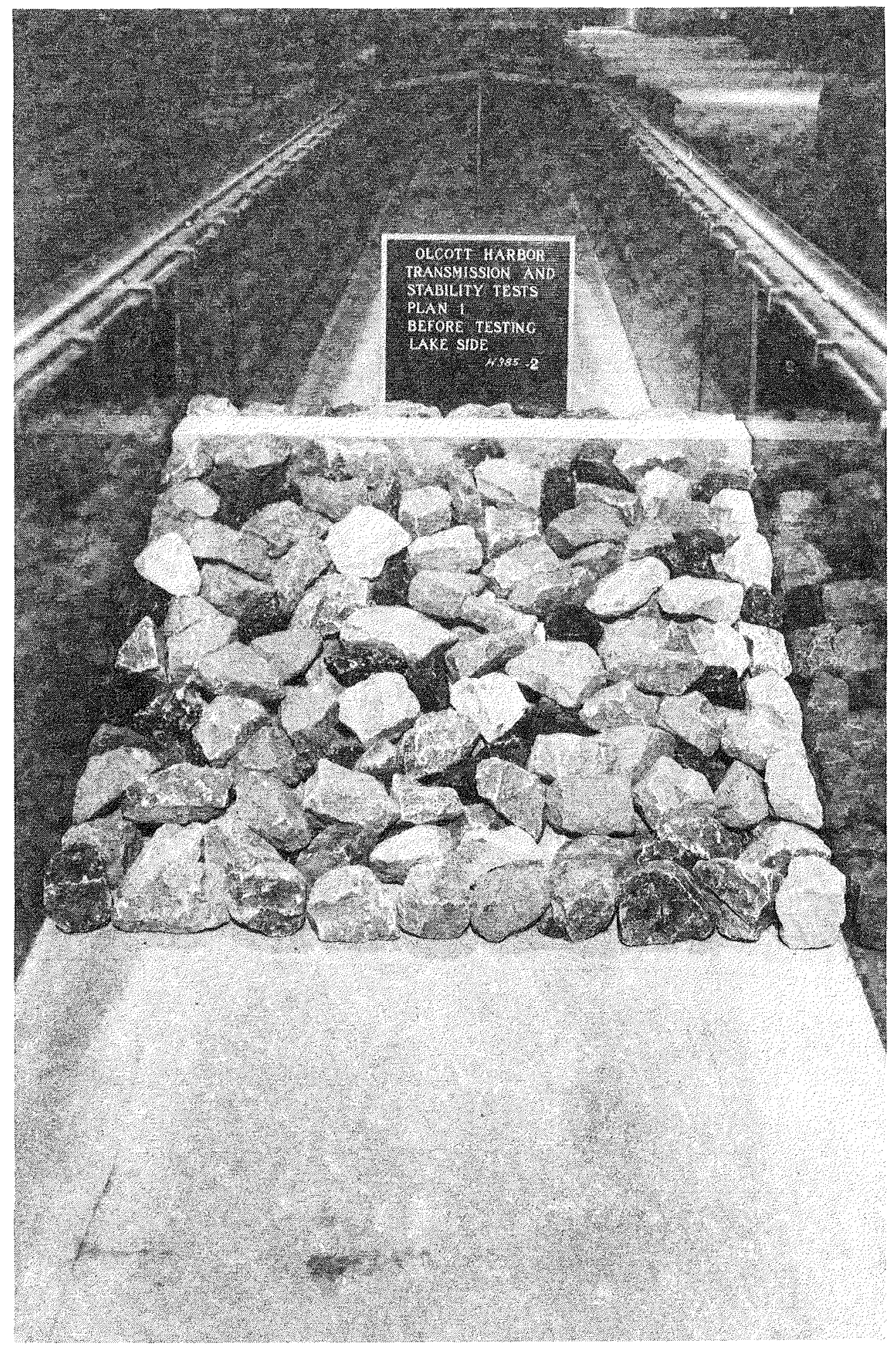

Photo 2. Lakeside view of Plan 1 before wave attack 


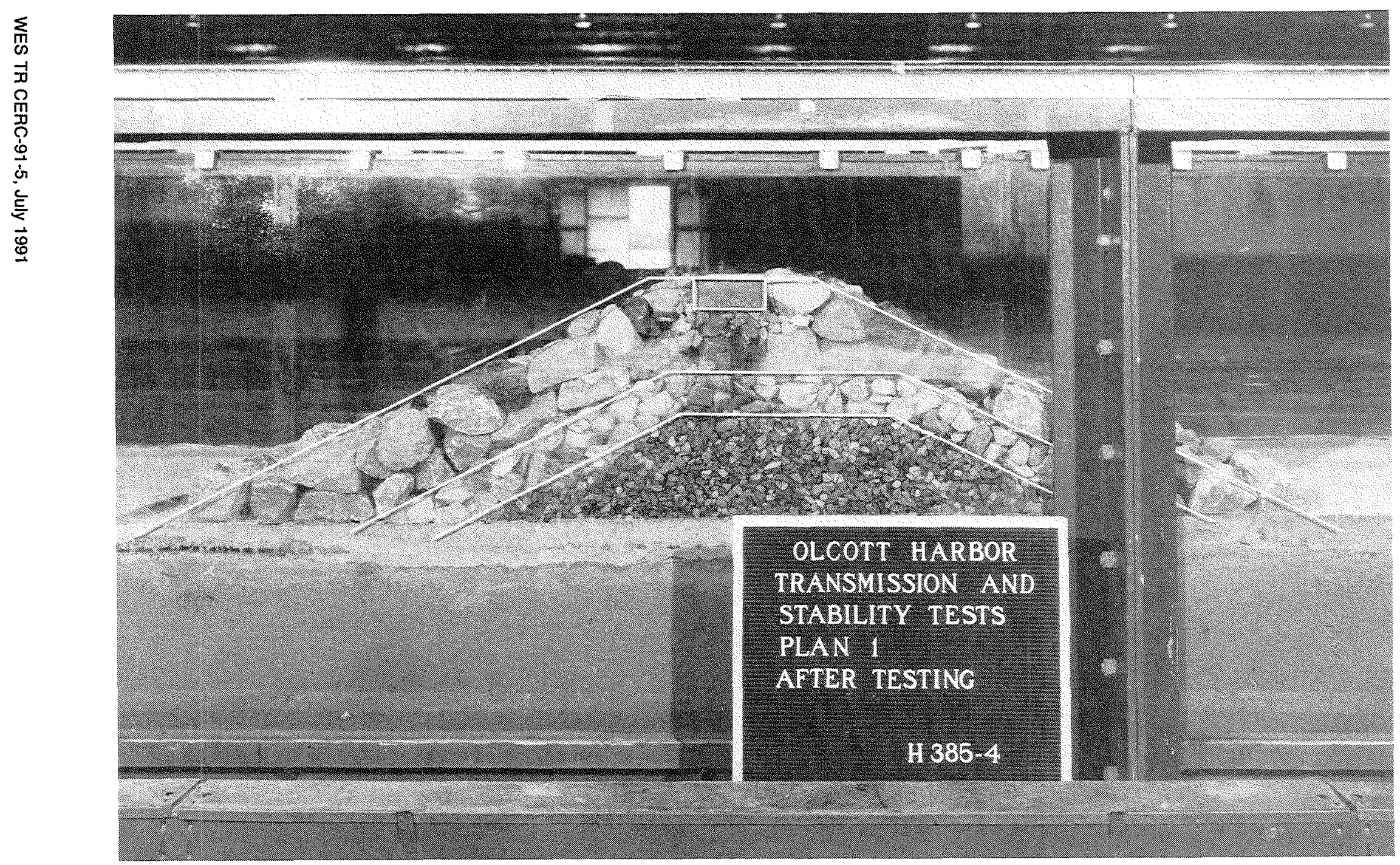

Photo 3. Side view of Plan 1 after wave attack 


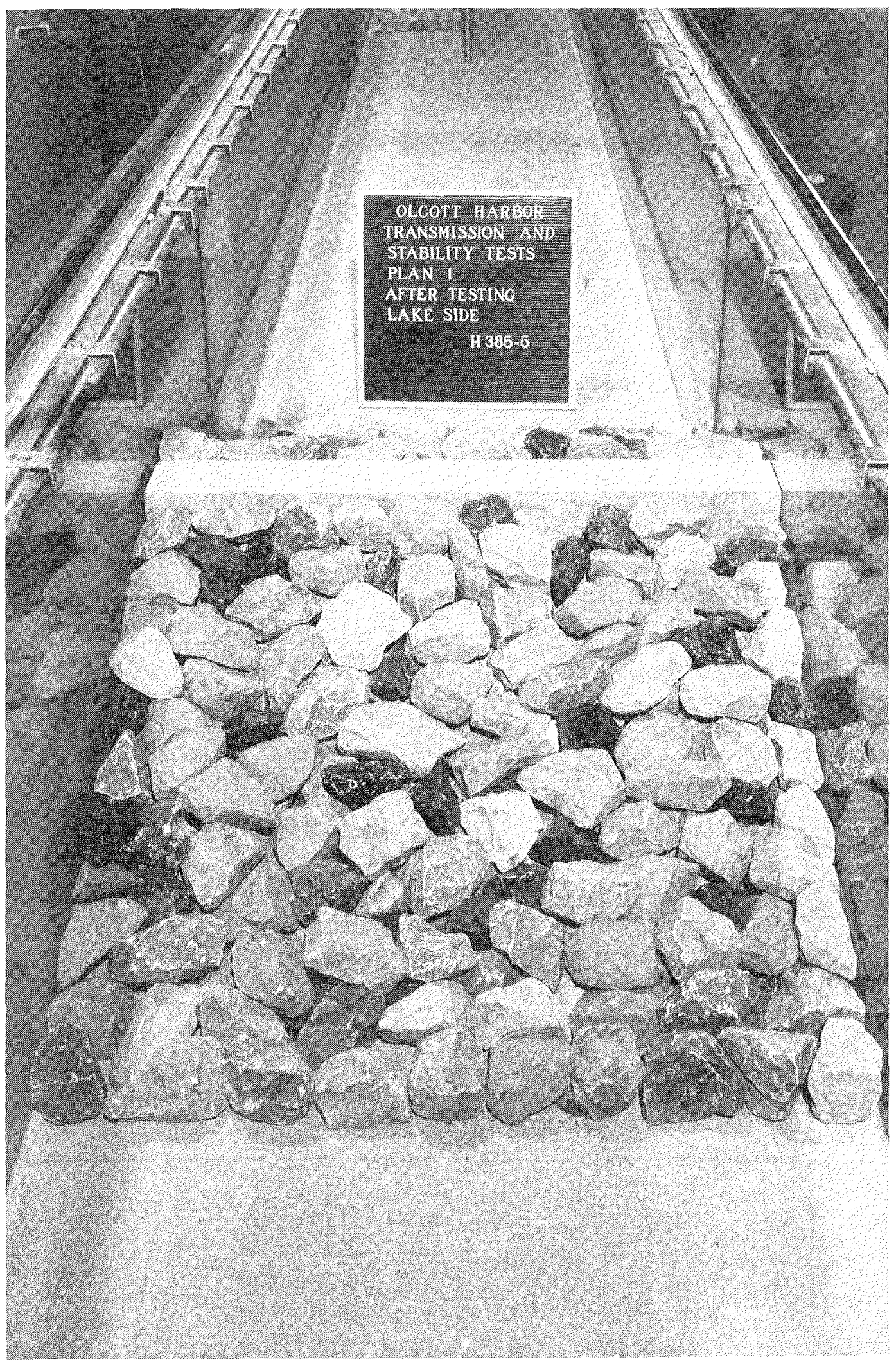

Photo 4. Lakeside view of Plan 1 after wave attack 


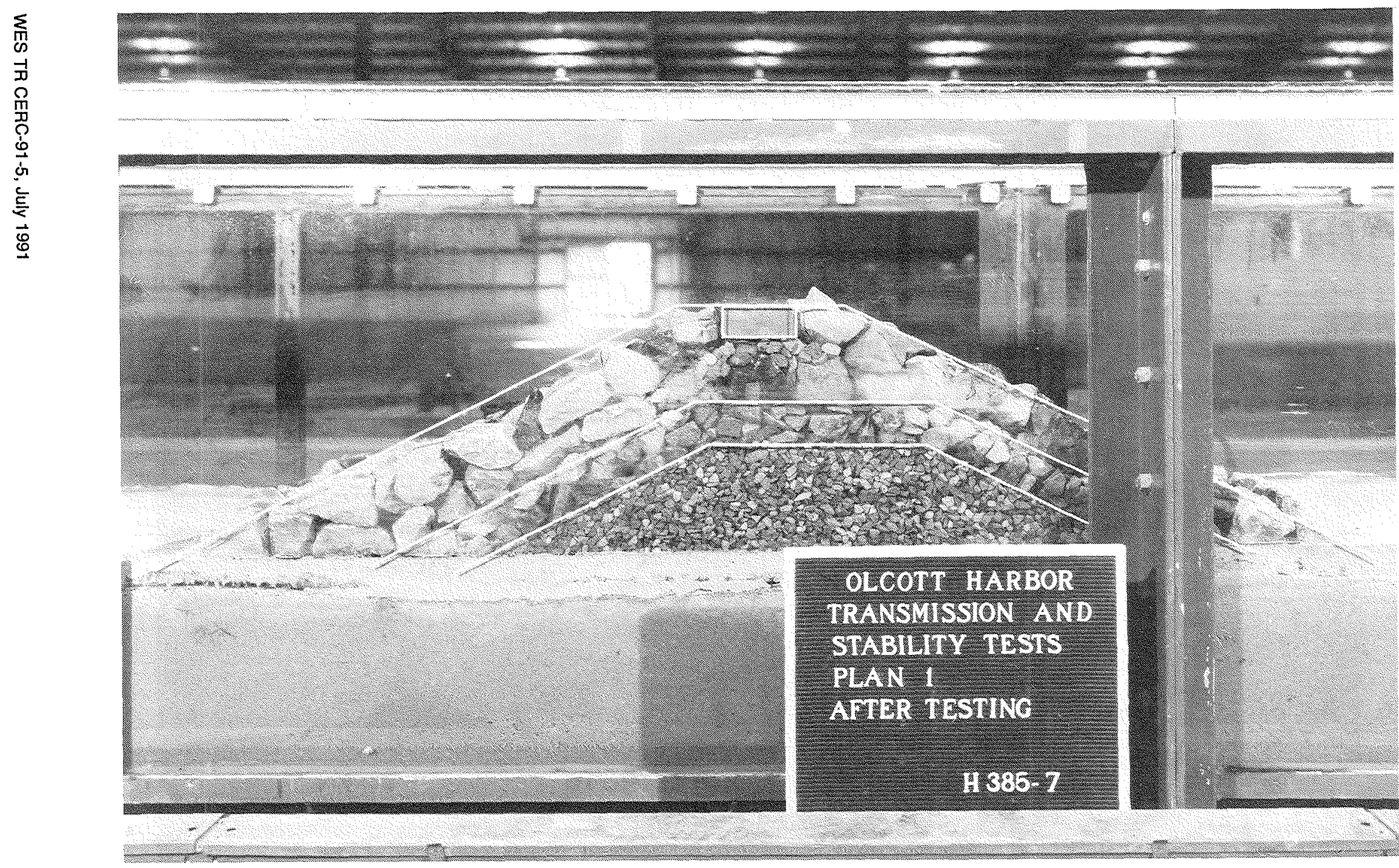

Photo 5. Side view of Plan $1 \mathrm{~A}$ after wave attack 


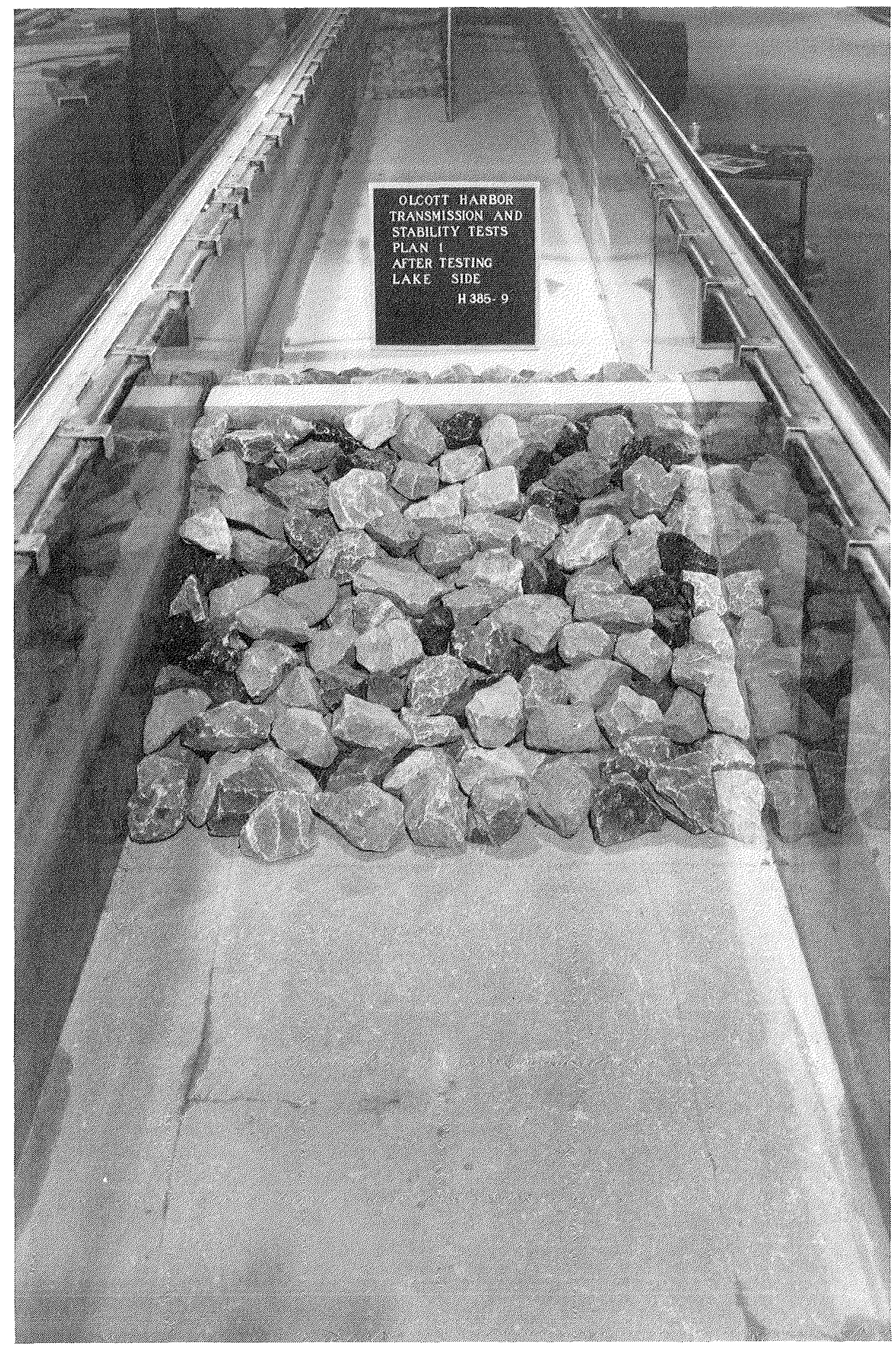

Photo 6. Lakeside view of Plan 1A after wave attack 


\title{
Appendix A Notation
}

\author{
A Area, $\mathrm{ft}^{2}$ \\ $\mathrm{C}_{\mathrm{t}} \quad$ Transmission coefficient $\left(\mathrm{H}_{\mathrm{t}} / \mathrm{H}_{\mathrm{i}}\right)$ \\ $\overline{\mathrm{C}}_{\mathrm{t}} \quad$ Average $\mathrm{C}_{\mathrm{t}}$ \\ $\mathrm{H}_{\mathrm{i}} \quad$ Incident wave height \\ $\mathrm{H}_{\mathfrak{t}} \quad$ Transmitted wave height \\ $\mathrm{H}_{\text {mo }} \quad$ Zero-moment wave height, $\mathrm{ft}$ \\ $\mathrm{L} \quad$ Length, linear scale, $\mathrm{ft}$
}

$\mathrm{S}_{\mathrm{a}} \quad$ Specific weight of an individual armor relative to the water in which the breakwater is constructed, i.e., $S_{a}=\gamma_{a} / \gamma_{w}$

T Time

$T_{p} \quad$ Wave period of peak energy density of spectrum, sec

$\mathrm{V} \quad$ Volume, $\mathrm{ft}^{3}$

$\mathrm{W}_{\mathrm{a}} \quad$ Weight of individual armor, $\mathrm{lb}$

$\gamma_{\mathrm{a}} \quad$ Specific weight of armor unit, pcf

Subscripts

a Refers to armor stone

m Refers to model quantities

p Refers prototype quantities

r Refers to ratio of model quantities to prototype quantities

w Refers to water 